\title{
PENGARUH BAURAN PEMASARAN TERHADAP KEPUASAN WISATAWAN MANCANEGARA DI PANTAI PANDAWA, KABUPATEN BADUNG, BALI
}

\author{
Ni Wayan Vitha Wahyundari \\ I Nyoman Sudiarta \\ Ni Putu Eka Mahadewi \\ Email : vithawahyundari@gmail.com \\ PS. S1 Industri Perjalanan Wisata \\ Fakultas Pariwisata UNUD
}

\begin{abstract}
ABSTRAK
Kepuasan wisatawan merupakan salah satu faktor penting dalam pengembangan suatu destinasi wisata. Bauran pemasaran sebagai salah satu alat pemasaran, dapat digunakan untuk memberikan kepuasan kepada wisatawan. Bauran pemasaran dalam bidang jasa terdiri dari produk, harga, promosi, tempat, orang, proses, serta sarana fisik. Pantai Pandawa merupakan salah satu destinasi wisata baru di Bali yang masih dalam proses pengembangan. Setelah dibukanya akses menuju Pantai Pandawa, wisatawan baik domestik maupun mancanegara banyak berdatangan ke pantai ini. Namun terlihat perbedaan yang sangat mencolok terhadap jumlah kunjungan wisatawan mancanegara yang jauh lebih sedikit dibandingkan dengan jumlah kunjungan wisatawan domestik di pantai ini. Untuk itu ingin diketahui bagaimana pengaruh bauran pemasaran terhadap kepuasan wisatawan mancanegara di Pantai Pandawa, yang hasilnya diharapkan dapat dijadikan acuan dalam upaya mengembangkan Pantai Pandawa, khususnya dalam meningkatkan jumlah kunjungan wisatawan mancanegara di Pantai Pandawa. Metode yang digunakan adalah teknik sampling non probabilitas, yaitu sampling insidental dengan menyebarkan 115 kuesioner kepada wisatawan mancanegara di Pantai Pandawa. Teknik analisis yang digunakan adalah deskriptif kuantitatif dengan menggunakan skala likert, analisis regresi berganda, koefisien determinasi, serta pengujian hipotesis melalui uji f dan uji t. Data yang diperoleh dianalisis menggunakan program SPSS. Hasil penelitian menunjukkan bahwa secara serentak atau simultan ketujuh unsur bauran pemasaran berpengaruh secara signifikan terhadap kepuasan wisatawan mancanegara di Pantai Pandawa. Hasil penelitian secara parsial menunjukkan bahwa variabel produk, harga, sarana fisik dan proses berpengaruh secara signifikan, sedangkan variabel tempat, promosi dan orang berpengaruh secara tidak signifikan terhadap kepuasan wisatawan mancanegara di Pantai Pandawa. Dalam penelitian ini disarankan kepada pengelola Pantai Pandawa untuk menambah aktivitas wisata air di pantai, menambah variasi menu pada rumah makan, menyediakan koneksi wifi, menata rumah makan agar lebih rapi, serta meningkatkan kebersihan fasilitas dan kebersihan lingkungan pantai.
\end{abstract}

Kata Kunci : Bauran Pemasaran, Kepuasan Wisatawan Mancanegara.

\section{PENDAHULUAN}

Sektor pariwisata bagi sejumlah negara telah menjadi andalan dan prioritas dalam meningkatkan dan mengembangkan perekonomian. Terlebih bagi negara Indonesia yang memiliki keindahan alam dan keberagaman budaya yang dapat menjadi daya tarik wisata andalan negeri ini. Setiap daerah di Indonesia memiliki ciri khas tersediri dan memiliki keunikan ragam budaya yang dapat menjadi daya tarik wisata sehingga dapat menarik minat wisatawan untuk mengunjungi daerah tersebut.

Pulau Bali merupakan salah satu destinasi wisata di Indonesia yang telah dikenal sampai ke mancanegara. Keindahan panorama alam dan budaya yang tersohor sampai ke 
mancanegara dapat menarik minat banyak orang untuk mengunjungi, berlibur atau pun berwisata ke pulau ini. Wisatawan yang datang mulai dari wisatawan nusantara sampai wisatawan mancanegara.

Sebagai destinasi wisata yang dikenal sampai ke mancanegara, Bali memiliki daya tarik wisata yang beragam, mulai dari daya tarik wisata alam, wisata budaya, maupun wisata bahari yang tersebar di seluruh penjuru pulau ini. Kabupaten Badung merupakan salah satu kabupaten di Bali yang memiliki destinasi-destinasi wisata terkenal dan memiliki daya tarik wisata pantai berpasir putih yang indah, seperti Pantai Kuta yang terkenal dengan sunsetnya, Pantai Tanjung Benoa yang terkenal dengan watersportnya, Pantai Kedonganan yang terkenal dengan seafoodnya, dan pantaipantai lainnya.

Pantai Pandawa merupakan salah satu pantai pasir putih yang ada di Kabupaten Badung, tepatnya terletak di Desa Kutuh, Kecamatan Kuta Selatan. Pantai Pandawa diresmikan pada bulan Desember 2012, sehingga pantai ini masih tergolong destinasi wisata baru. Keunikan pantai Pandawa sudah dapat dirasakan mulai dari akses masuk ke kawasan pantai yang dikelilingi oleh tebing karang yang menjulang tinggi. Di sepanjang sisi tebing Pantai Pandawa, terdapat lima patung Pandawa dan Dewi Kunti. Nama Pantai Pandawa terinspirasi dari nama tokoh yang diambil dari legenda Mahabharata. Sejak dibukanya akses menuju Pantai Pandawa, wisatawan baik domestik maupun mancanegara mulai berdatangan ke pantai ini.

Jumlah kunjungan wisatawan ke Pantai Pandawa dua tahun terakhir dari tahun 2013 ke tahun 2014 mengalami peningkatan yang cukup drastis. Peningkatan kunjungan ini didominasi oleh wisatawan domestik dimana pada tahun 2013 kunjungan wisatawan domestik sebanyak 337.911 orang dan pada tahun 2014 meningkat menjadi 1.260 .996 orang, atau mengalami peningkatan sebesar 273,2 persen. Untuk kunjungan wisatawan mancanegara yaitu sebanyak 80.577 orang pada tahun 2013 dan mengalami peningkatan sebesar 40,68 persen menjadi 113.363 orang pada tahun 2014 (Kepala Penataan Pantai Pandawa, 2015). Dapat dilihat bahwa terdapat perbedaan yang mencolok antara jumlah kunjungan wisatawan domestik dengan jumlah kunjungan wisatawan mancanegara di Pantai Pandawa. Hal ini berarti upaya pengembangan Pantai Pandawa masih perlu ditingkatkan agar pantai ini lebih dikenal di dunia internasional sebagai salah satu daya tarik wisata di Bali, sehingga nantinya dapat menarik lebih banyak kunjungan wisatawan mancanegara ke Pantai Pandawa.

Bauran pemasaran adalah salah satu alat dalam bidang pemasaran yang dapat digunakan untuk mengembangkan suatu industri jasa pariwisata khususnya daya tarik wisata. Bauran pemasaran merupakan suatu perangkat yang akan menentukan tingkat keberhasilan pemasaran bagi suatu industri, dan hal ini ditujukan agar segmen pasar agar mendapatkan kepuasan. Konsep bauran pemasaran jasa terdiri dari bauran pemasaran tradisional (traditional marketing mix) dan bauran pemasaran jasa yang diperluas (expanded marketing mix for services) dengan penambahan unsur non-tradisional marketing mix, sehingga terdiri dari 7P yaitu produk (product), harga (price), promosi (promotion), tempat (place), orang (people), sarana fisik (physical evidence) dan proses (process) (Zeithaml dan Bitner, 2003: 24).

Ketujuh unsur dari bauran pemasaran tersebut dapat digunakan untuk memberikan kepuasan kepada wisatawan. Kepuasan wisatawan merupakan salah satu faktor penting dalam pengembangan suatu daya tarik wisata. Kepuasan adalah perasaan senang atau kecewa yang dirasakan oleh seseorang yang muncul setelah membandingkan antara persepsi atau kesannya terhadap kinerja suatu produk dan harapan-harapannya (Kotler, 2002: 42). Jika wisatawan merasa puas atas kunjungannya di suatu daya tarik wisata, kemungkinan besar wisatawan tersebut akan kembali mengunjungi daya tarik wisata dan akan merekomendasikannya kepada orang lain. Sehingga secara tidak langsung kepuasan wisatawan menyebabkan kenaikan jumlah kunjungan dan dapat memberikan dampak yang baik terhadap perkembangan daya tarik wisata tersebut.

Bauran pemasaran dapat digunakan oleh pengelola Pantai Pandawa dalam mengembangkan dan mempromosikan Pantai Pandawa agar dapat mendatangkan lebih banyak wisatawan mancanegara ke pantai ini. Dengan mengetahui unsur-unsur Bauran Pemasaran yang berpengaruh terhadap kepuasan wisatawan mancanegara di Pantai Pandawa, diharapkan pengelola mampu meningkatkan dan lebih memperhatikan unsur tersebut sehingga nantinya dapat memberikan 
kepuasan kepada wisatawan mancanegara. Terciptanya kepuasan wisatawan mancanegara akan memberikan dampak yang baik bagi pengembangan dari Pantai Pandawa yang secara tidak langsung akan menyebabkan wisatawan tersebut datang kembali, melakulan pembelian ulang, serta merekomendasikannya kepada teman atau saudaranya, sehingga nantinya dapat mendatangkan lebih banyak wisatawan mancanegara untuk berkunjung ke Pantai Pandawa.

Ketujuh unsur dari bauran pemasaran akan digunakan sebagai variabel dalam mengukur kepuasan wisatawan mancanegara dan untuk mengetahui pengaruhnya terhadap kepuasan wisatawan mancanegara di Pantai Pandawa. Untuk itu ingin diketahui bagaimana pengaruh bauran pemasaran terhadap kepuasan wisatawan mancanegara di Pantai Pandawa.

\section{METODE}

Variabel yang digunakan terdiri dari 7 variabel independen (Produk, Tempat, Harga, Promosi, Orang, Sarana Fisik, dan Proses) dan 1 variabel dependen (Kepuasan Wisatawan mancanegara), dengan total 23 indikator. Teknik penentuan sampel yang digunakan adalah dengan non-probability sampling, yaitu accidental sampling dengan menyebarkan 115 kuesioner kepada Wisatawan mancanegara di Pantai Pandawa. Teknik analisis data yang digunakan adalah deskriptif kuantitatif. Data kuantitatif diperoleh dengan menggunakan skala likert. Data yang diperoleh kemudian dianalisis menggunakan bantuan program SPSS 16.0. Tahap-tahap dalam analisis data yaitu dengan melakukan Uji Kualitas Data (Uji Validitas dan Reliabilitas), Uji Asumsi Klasik (Uji Normalitas, Uji Heteroskedastisitas, dan Uji Multikolinearitas), kemudian melakukan Analisis Regresi Berganda, Uji Koefisien Determinasi, serta Uji Hipotesis (Uji t dan Uji F).

\section{PEMBAHASAN \\ Hasil Uji Kualitas Data}

Hasil Uji Validitas

Berdasarkan hasil uji validitas data didapatkan hasil nilai $r$ hitung dari setiap butir penyataan/ indikator bernilai positif dan lebih besar dari nilai yang tertera pada $r$ tabel. Maka dapat disimpulkan bahwa semua item indikator dalam penelitian ini dinyatakan valid.

\section{Hasil Uji Reliabilitas}

Berdasarkan uji reliabilitas yang telah dilakukan, didapatkan hasil yaitu semua variabel memiliki nilai Cronbach's Alpha lebih besar daripada 0,60. Sehingga setiap item pada variabel dalam kuesioner adalah reliabel atau handal.

\section{Hasil Uji Asumsi Klasik}

1. Hasil Uji Normalitas

Berdasarkan grafik histogram, data memiliki pola distribusi yang simetris atau tidak menceng (skewness). Dilihat dari grafik normal probability plot, data (titik) menyebar disekitar garis diagonal dan mengikuti arah garis diagonal. Dari kedua grafik tersebut maka dapat disimpulkan bahwa model regresi memenuhi asumsi normalitas.

2. Hasil Uji Multikolinearitas

Berdasarkan hasil pengolahan data, keseluruhan variabel independen memiliki nilai Tolerance lebih besar atau sama dengan 0,10 dan memiliki nilai VIF lebih kecil atau sama dengan 10 . Hal ini berarti bahwa semua variabel independen tidak mengalami multikolinearitas.

3. Hasil Uji Heteroskedastisitas

Berdasarkan grafik scatterplot, terlihat bahwa titik-titik menyebar secara acak dan tersebar dengan baik di atas maupun di bawah angka 0 pada sumbu Y. Persebaran data juga tidak membentuk pola tertentu. Jadi dapat disimpulkan bahwa tidak terjadi gejala heteroskedastisitas pada model regresi.

\section{Hasil Uji Koefisien Determinasi}

Hasil uji koefisien determinasi menunjukkan bahwa sebesar $61,7 \%$ keragaman kepuasan wisatawan mancanegara di Pantai Pandawa dipengaruhi oleh adanya faktor-faktor bauran pemasaran yang terdiri dari produk, harga, tempat, promosi, orang, sarana fisik, dan proses. Sedangkan sisanya yaitu $(100 \%-61,7 \%$ $=38,3 \%$ ) dipengaruhi oleh faktor lain yang tidak diteliti dalam penelitian ini. 


\section{Hasil Analisis Regresi Berganda, Uji t dan Uji F}

Berikut persamaan regresi yang terbentuk berdasarkan hasil analisis yang telah dilakukan. $\mathrm{Y}=-120+0,288 \mathrm{X}_{1}+0,169 \mathrm{X}_{2}+0,066 \mathrm{X}_{3}$ $0,061 \mathrm{X}_{4}+0,131 \mathrm{X}_{5}+0,318 \mathrm{X}_{6}+0,155 \mathrm{X}_{7}$

Tabel 3. Hasil Uji F

\begin{tabular}{|l|r|r|r|r|r|}
\hline \multicolumn{1}{|l|}{ Model } & $\begin{array}{c}\text { Sum of } \\
\text { Squares }\end{array}$ & Df & $\begin{array}{c}\text { Mean } \\
\text { Square }\end{array}$ & F & Sig. \\
\hline $1 \quad$ Regression & 39.752 & 7 & 5.679 & 27.288 & $.000^{\mathrm{a}}$ \\
& 22.268 & 107 & .208 & & \\
Residual & 62.019 & 114 & & & \\
Total & & & \\
\hline
\end{tabular}

Berdasarkan persamaan regresi tersebut, enam variabel dari bauran pemasaran (produk, tempat, harga, orang, sarana fisik, dan proses) memiliki koefisien regresi positif. Hal ini berarti setiap peningkatan dari masing-masing keenam variabel tersebut juga akan mengakibatkan peningkatan dari kepuasan wisatawan mancanegara di Pantai Pandawa. Sedangkan variabel promosi memiliki koefisien regresi negatif yang berarti setiap peningkatan dari variabel promosi akan menyebabkan penurunan dari kepuasan wisatawan mancanegara di Pantai Pandawa.

Tabel 2. Hasil Uji t

\begin{tabular}{|l|c|c|c|}
\hline Variabel Bebas & t hitung & Signifikansi & Keterangan \\
\hline Produk (X1) & 3.102 & 0.002 & Signifikan \\
\hline Harga (X2) & 2.253 & 0.026 & Signifikan \\
\hline Tempat (X3) & 0.767 & 0.445 & $\begin{array}{c}\text { Tidak } \\
\text { Signifikan }\end{array}$ \\
\hline Promosi (X4) & -0.993 & 0.323 & $\begin{array}{c}\text { Tidak } \\
\text { Signifikan }\end{array}$ \\
\hline Orang (X5) & 1.348 & 0.180 & $\begin{array}{c}\text { Tidak } \\
\text { Signifikan }\end{array}$ \\
\hline $\begin{array}{l}\text { Sarana Fisik } \\
\text { (X6) }\end{array}$ & 3.715 & 0.000 & Signifikan \\
\hline Proses (X7) & 1.988 & 0.049 & Signifikan \\
\hline
\end{tabular}

Berdasarkan tabel uji $t$, variabel produk, harga, sarana fisik, dan proses memiliki nilai $\mathrm{t}$ hitung $>\mathrm{t}$ tabel dan taraf signifikansi $<0,05$, maka dapat disimpulkan bahwa keempat variabel tersebut secara parsial memiliki pengaruh signifikan terhadap kepuasan wisatawan mancanegara di Pantai Pandawa. Sedangkan untuk variabel tempat, promosi, dan orang memiliki nilai $\mathrm{t}$ hitung $<\mathrm{t}$ tabel dan taraf signifikansi $>0,05$ yang berarti bahwa ketiga variabel tersebut secara parsial memiliki pengaruh tidak signifikan terhadap
Tabel 1. Hasil Analisis Regresi Berganda

\begin{tabular}{|l|r|r|r|r|r|}
\hline \multirow{2}{*}{ Model } & \multicolumn{2}{|c|}{$\begin{array}{c}\text { Unstandardized } \\
\text { Coefficients }\end{array}$} & $\begin{array}{c}\text { Standardized } \\
\text { Coefficients }\end{array}$ & & \\
\cline { 2 - 4 } & \multicolumn{1}{c|}{$\mathrm{B}$} & Std. Error & \multicolumn{1}{|c|}{ Beta } & \multicolumn{1}{c|}{$\mathrm{t}$} & Sig. \\
\hline (Constant) & -.120 & .317 & & -.378 & .706 \\
Produk & .288 & .093 & .244 & 3.102 & .002 \\
Harga & .169 & .075 & .176 & 2.253 & .026 \\
Tempat & .066 & .086 & .056 & .767 & .445 \\
Promosi & -.061 & .062 & -.068 & -.993 & .323 \\
Orang & .131 & .098 & .117 & 1.348 & .180 \\
Sarana Fisik & .318 & .086 & .311 & 3.715 & .000 \\
Proses & .169 & .085 & .155 & 1.988 & .049 \\
\hline
\end{tabular}

kepuasan wisatawan mancanegara di Pantai Pandawa.

Berdasarkan tabel uji $\mathrm{F}$ diperoleh nilai $\mathrm{F}$ hitung $>\mathrm{F}$ tabel $(27.288>2.10)$, dan nilai signifikansi lebih kecil dari $0,05 \quad(0,000<$ $0,05)$, yang berarti bahwa variabel produk, harga, tempat, promosi, orang, sarana fisik, dan proses secara bersama-sama atau simultan berpengaruh signifikan terhadap kepuasan Wisatawan mancanegara di Pantai Pandawa.

Berdasarkan analisis regresi berganda yang telah dilakukan, masing-masing dari enam variabel bauran pemasaran yang terdiri dari produk, tempat, harga, orang, sarana fisik, dan proses dapat mengakibatkan kenaikan dari kepuasan wisatawan mancanegara di Pantai Pandawa apabila masing-masing dari keenam unsur tersebut mengalami peningkatan atau lebih diperhatikan oleh pengelola Pantai Pandawa. Sedangkan untuk variabel promosi tidak berpengaruh positif terhadap kepuasan wisatawan mancanegara di Pantai Pandawa dikarenakan promosi yang dilakukan di media promosi belum efektif dalam medatangkan lebih banyak wisatawan mancanegara ke Pantai Pandawa. Strategi promosi yang sesuai untuk Pantai Pandawa harus diperhatikan agar dapat menarik lebih banyak wisatawan untuk datang ke Pantai Pandawa.

Ketujuh variabel bauran pemasaran secara simultan atau bersama-sama berpengaruh signifikan terhadap kepuasan wisatawan mancanegara di Pantai Pandawa dapat dikarenakan ketujuh unsur bauran pemasaran tersebut saling melengkapi di dalam suatu daya tarik wisata, khususnya di Pantai Pandawa. Di Pantai Pandawa ada 
produk yang ditawarkan, kemudian harga diberlakukan untuk produk tersebut, tempat merupakan lokasi Pantai Pandawa, promosi merupakan upaya yang dilakukan pengelola untuk memperkenalkan Pantai Pandawa kepada wisatawan, orang adalah semua pelaku yang berperan dalam memberikan jasa di Pantai Pandawa, sarana fisik merupakan lingkungan fisik Pantai Pandawa, serta Proses merupakan mekanisme dalam penyampaian jasa di Pantai Pandawa. Keseluruhan unsur Bauran Pemasaran tersebut saling terkait dan mendukung satu sama lainnya di Pantai Pandawa sehingga dapat berpengaruh secara signifikan dalam memberikan kepuasan kepada Wisatawan Mancanegara di Pantai Pandawa.

Pengaruh ketujuh unsur bauran pemasaran secara parsial atau individual terhadap kepuasan wisatawan mancanegara di Pantai Pandawa adalah sebagai berikut.

a. Variabel produk berpengaruh secara signifikan terhadap kepuasan wisatawan mancanegera di Pantai Pandawa dikarenakan pantai ini menawarkan pemandangan pantai pasir putih indah dan air lautnya yang biru jernih yang dapat memberikan kepuasan tersendiri kepada wisatawan yang berkunjung ke pantai ini. Selain itu suasana yang tenang dan nyaman dapat menambah kenyamanan wisatawan asing yang lebih menyukai ketenangan, dan dengan disediakannya fasilitas wisata air seperti kano dapat menambah kesenangan berwisata ke Pantai Pandawa. Di Pantai Pandawa juga telah disediakan berbagai fasilitas untuk wisatawan, seperti payung pantai, rumah makan/restoran, toko souvenir, spa, toilet/shower, dan tempat parkir.

b. Variabel harga berpengaruh secara signifikan terhadap kepuasan wisatawan mancanegara di Pantai Pandawa dikarenakan harga makanan dan minuman yang ditawarkan di rumah makan/ restoran terjangkau dan sesuai dengan kualitas makanan yang didapatkan oleh wisatawan, selain itu untuk harga tiket masuk dan fasilitas wisata seperti kano dan payung pantai juga terjangkau bagi wisatawan asing.

c. Variabel tempat berpengaruh tidak signifikan terhadap kepuasan wisatawan dapat dikarenakan wisatawan mancanegara lebih fokus dengan apa yang ditawarkan dan pelayanan di Pantai Pandawa dibandingkan dengan kondisi jalan/ akses, keadaan tempat parkir, dan petunjuk arah, dikarenakan sebagian besar dari wisatawan tersebut datang ke Pantai Pandawa dengan sopir/ taksi sehingga mereka tidak terlalu mempedulikan keadaan tersebut.

d. Variabel promosi dalam penelitian ini, yaitu promosi Pantai Pandawa melalui media promosi berpengaruh tidak signifikan terhadap kepuasan wisatawan mancanegara dapat dikarenakan sebagian besar wisatawan tersebut mendapatkan informasi mengenai Pantai Pandawa dari teman/ keluarga, rekomendasi hotel, sopir taksi, serta pemandu wisata. Sehingga mereka tidak terlalu mempermasalahkan kuantitas dan kualitas dari penayangan iklan di media promosi.

e. Variabel orang berpengaruh tidak signifikan terhadap kepuasan wisatawan mancanegara dapat dikarenakan interaksi yang minim antara petugas di Pantai Pandawa dengan wisatawan bukanlah hal yang terlalu mempengaruhi kepuasan akan kunjungan wisatawan tersebut di Pantai Pandawa. Wisatawan mancanegara lebih senang menghabiskan waktunya untuk berjemur dan bersantai di pantai dalam suasana yang tidak ramai.

f. Variabel sarana fisik berpengaruh secara signifikan terhadap kepuasan wisatawan mancanegera di Pantai Pandawa dikarenakan wisatawan sangat memperhatikan faktor kenyamanan dan kebersihan dari lingkungan pantai, keindahan dari destinasi wisata dan daya tariknya, serta fasilitas yang ditata dengan baik.

g. Variabel proses berpengaruh secara signifikan terhadap kepuasan Wisatawan mancanegara di Pantai Pandawa dapat dikarenakan pelayanan adalah salah satu faktor yang menentukan kepuasan dari wisatawan tersebut. Wisatawan mancanegara yang menganggap pelayanan yang diberikan baik dan cepat ketika menerima produk atau jasa, maka wisatawan tersebut akan merasa puas. 


\section{SIMPULAN DAN SARAN \\ Simpulan}

Berdasarkan pembahasan yang telah dipaparkan, maka dapat ditarik simpulan sebagai berikut.

1. Secara serentak atau simultan, ketujuh unsur dari bauran pemasaran yang terdiri dari produk, harga, tempat, promosi, orang, sarana fisik, serta proses berpengaruh signifikan terhadap kepuasan wisatawan di Pantai Pandawa.

2. Secara parsial atau individual, variabel produk, harga, sarana fisik, dan proses memiliki pengaruh signifikan terhadap kepuasan wisatawan mancanegara di Pantai Pandawa. Sedangkan untuk variabel tempat, promosi, dan orang memiliki pengaruh tidak signifikan terhadap kepuasan wisatawan mancanegara di Pantai Pandawa.

\section{Saran}

Berdasarkan hasil pembahasan, dapat diberikan saran sebagai berikut:

1. Bagi pengelola Pantai Pandawa berkaitan dengan variabel Produk, sebaiknya menyediakan tambahan aktivitas wisata bagi wisatawan seperti snorkeling, menyediakan lebih banyak variasi menu dan masakan internasional di rumah makan/ restoran, serta menyediakan lebih banyak koneksi wifi untuk wisatawan. Berkaitan dengan variabel Sarana Fisik, sebaiknya pengelola Pantai Pandawa memperhatikan fasilitas wisata yang ada seperti restoran/ rumah makan agar ditata dengan lebih rapi. Selain itu, kebersihan lingkungan, kebersihan pantai serta kebersihan fasilitas (toilet) di Pantai Pandawa perlu ditingkatkan agar wisatawan yang berkunjung merasa lebih nyaman.

2. Untuk selanjutnya dapat diperluas indikator terutama yang berkaitan dengan variabel tempat dan proses sehingga lebih sesuai dengan konsep yang digunakan.

\section{DAFTAR PUSTAKA}

Kepala Penataan Pantai Pandawa. 2015. Data Jumlah Kunjungan Wisatawan ke Pantai Pandawa Tahun 2013-2014.
Kotler, Philip. 2002. Manajemen Pemasaran. Edisi Milenium, Jilid 1 dan 2. Jakarta: PT Prenhallindo

Zeithaml, Valarie A dan Mary Jo Bitner. 2003. Services Marketing: Integrating Customer Focus Across The Firm. New York: McGraw- Hill 